\title{
Sissejuhatus
}

\section{KoHUS JA KOHTUPIDAmine Eesti ÕIgUSAJAloos}

\author{
Marju Luts-Sootak, Hesi Siimets-Gross
}

Kuigi ajaloolastel ja õigusajaloolastel on kokkupuutepunkte nii allikate baasil kui igapäevases teadustegevuses ja õppetööski päris palju, jõudis õigusajaloolaste koostatud teemanumber Ajaloolisse Ajakirja viimati peaaegu kakskümmend aastat tagasi, 1998 . aastal. ${ }^{1}$ Sellest ajast ei ole mitte ainult palju vett merre voolanud, vaid muutunud on nii Ajaloolise Ajakirja väljaandja, formaat kui ka õigusajaloolise teemanumbri uurimisteemad.

Juba tollal juhtis Toomas Anepaio tähelepanu sellele, et näiteks Saksa õigusajaloo uurijad on seadusandluse ja õigusnormide uurimiselt liikunud üha enam õigustegelikkuse uurimisele, mille tulemusena käsitletakse järjest enam mitmesuguseid institutsioone, õigusemõistmist, selle sisemist struktuuri ja konkreetset kohtupraktikat. ${ }^{2}$ 1998. aasta erinumber sisaldas siiski eelkõige õigusallikate ja õigusharidusega seotud käsitlusi, erandiks olid kaks ajaloolaste kirjutatud artiklit vallakohtutest.

Käesolevat teemanumbrit koostades ja numbrile pealkirja valides avastasime peaaegu eneselegi üllatuslikult, et siia koondatud ja eelkõige Tartu ülikooli õigusteaduskonnas töötavate või õppivate õigusajaloolaste aktuaalsed artiklid käsitlevadki just õigusemõistmist ning õigusemõistmisega seotud institutsioone ja isikuid, ehkki eri ajastutest. Sama käib ka nende artiklite kohta, mis on siia jõudnud väljastpoolt õigusteaduskonda. Nii kujunes teemanumbri pealkirjaks mõneti paratamatult "Kohus ja kohtupidamine Eesti õigusajaloos". Naljaga pooleks võiks ju väita, et Eesti õigusajalooline uurimine on paarikümne aastaga sakslastele järele jõudnud. Ehkki uurimisobjektiks on siin üksnes Eesti õigusajalugu ning loomulikult on see eelkõige eestlaste ülesanne (Helsingi ülikooli võrdleva õigusajaloo professor Heikki Pihlajamäki ühe artikli kaasautorina on siin erand), on tegemist ikkagi äärmiselt rahvusvahelise valdkonnaga nii õigusallikate ja kohtupidamise keele kui ka seda mõjutanud isikute ja tegurite poolest.

\footnotetext{
1 Ajalooline Ajakiri, 3 (1998), $126 \mathrm{lk}$.

2 Toomas Anepaio, "Kahe ilma piiril: võimalikke murdekohti Eesti õigusajaloos ja selle uurimises", Ajalooline Ajakiri, 3 (1998), 5.
} 
Teemanumber on üles ehitatud kronoloogiliselt. Temaatiliselt esimene artikkel "Tartu õuekohus kui õigussiire: Svea ja Liivimaa apellatsioonikohtute võrdlus” Heikki Pihlajamäelt ja Marju Luts-Sootakilt käsitleb Tartu ouekohtu asutamist ja selles toimunud kohtupidamist Rootsi kuningriigi suurvõimuperioodil. Senistest uurimustest eristab seda artiklit eelkõige Tartu õuekohtu arhiivimaterjalide põhjalik kasutamine ning kohtumenetluse ja õigusallikate analüüs rahvusvahelises kontekstis ja võrdluses Rootsi riigi teiste provintsidega. Kuna Tartu õuekohtu eelkäija ja eeskuju oli Stockholmis asutatud Svea õuekohus, annab just nende kahe kohtu võrdlemine aimu ka sellest, mil viisil aitas õuekohtu asutamine kaasa uute provintside integreerimisele Rootsi konglomeraatriiki.

Katre Kaju artiklis "Mitte ainult õigusest ehk Kohtuasi kui haridusja kirjanduslooline allikas" on analüüsitud 1667. aastast alguse saanud kohtuprotsessi materjale, andes ülevaate menetlusdokumentidest, mida ühest 17. sajandi kohtutoimikust leida võib. Arhiivis säilitatakse väga palju kohtutoimikuid, -protokolle, vaidlustes ja süüasjades kasutatud tõendeid või nende kirjeldusi, varaloendeid jne; muu hulgas ka armastusluuletusi, nagu ilmneb K. Kaju artiklist. Tihti on tegemist täiesti uurimata materjalidega või on neid uuritud vaid spetsiifiliselt õigusajaloolisest vaatevinklist. Tegelikult võiksid need pakkuda huvitavat ja informatiivset uurimisainest ka sotsiaal-, kultuuri-, majandus-, mentaliteedi- ja muudelegi ajaloolastele. Olgu K. Kaju artikkel selle kinnituseks ja teistele innustuseks.

Katrin Kello ja Hesi Siimets-Grossi artikkel "Kohtuasjad in puncto libertatis: isiku staatuse tuvastamise lähtekohad asehaldusaja Eestimaal" tegeleb ajaliselt veidi üle sajandi hilisema materjaliga ja käsitleb isiku vabadust puudutavaid kohtuprotsesse Eestimaa provintsi kohtutes Katariina II ajal. Analüüsitud on poolte seisukohti ja kohtute otsuseid erinevates kohtuastmetes, andes võimaluse jälgida õigusallikate kasutamist ja kohtupraktika kujunemist 18. sajandi lõpul, kui Eestimaa kubermang oli olnud juba mõnda aega Vene impeeriumi koosseisus. Erilist tähelepanu on pööratud sellele, kas ja kuidas kasutati Rooma orjaõiguse norme talupoegade vabadusprotsessides. Et seda tehti, ei ole üllatav. Küll aga on üllatav, et Vana-Rooma orjaõigusest pärit põhimõtted olid kasutusel just vabadusnõuete toetuseks.

Järgnevad kolm artiklit käsitlevad juba 20. sajandit, kahe maailmasõja vahelist perioodi. Merike Ristikivi, Marju Luts-Sootaki ja Heli-Triin Räisi artiklis on käsitletud Eesti naisjuristide pürgimist kohtunikuks sellel ajal. Ka siin võib lõpptulemuse juba ette ära öelda, et kuigi leidus naisi, kes küll soovisid saada (esialgu üksnes) kohtunikuameti kandidaatideks, neile seda võimalust ei antud. Nagu tänapäeval, nii ka tollal tõstatati seepeale 
küsimus põhiseaduslikult tagatud võrdõiguslikkusest. Marelle Leppiku artiklis "Soolise võrdõiguslikkuse küsimus Eesti Vabariigi põhiseadustes ja riigikohtu praktikas 1920-1940" uuritaksegi põhjalikumalt, mida peeti soolise diskrimineerimise keelu all silmas tollastes põhiseadustes ja vastavates aruteludes ning kas ja millisel moel jõudis sooline võrdõiguslikkus probleemina riigikohtu praktikasse.

Teemanumbri lõpetab Hannes Vallikivi artikkel "Kohtunike valiku kriteeriumid Eesti Vabariigis 1934-1940". Kuigi kohtunike valiku kriteeriumid ei olnud otsesõnu seadustes sätestatud, peeti kohtunike sõltumatust oluliseks ka sel ajal - ja just selleks ongi kriteeriumid vajalikud. Artiklis analüüsitakse, milliste kriteeriumide alusel toimus kohtunike valik "vaikival ajastul" ja kuivõrd sai neid valikuid mõjutada riigipea subjektiivne eelistus või meelevald.

Koostajatena seda teemanumbrit lõpetades loodame väga, et järgmise õigusajaloo numbri valmimine ei võta paarikümmet aastat ja me saame juba õige pea tuua ajaloolaste nõudliku ning asjatundliku publiku ette oma uuemad uurimused mõnest teisest valdkonnast Eesti õigusajaloos. Käesoleva teemanumbri avaldamist on toetanud Eesti Teadusfond (ETF9209) ja Eesti Teadusagentuur (IUT20-50). 
